\title{
Overwintering of Vaccinium vitis-idaea in two sub-Arctic microhabitats: a reciprocal transplantation experiment
}

\author{
Timo Saarinen \& Robin Lundell \\ Department of Biosciences, FI-00014 University of Helsinki, PO Box 65, Helsinki, Finland
}

\author{
Keywords \\ Chlorophyll fluorescence; electrolyte leakage; \\ overwintering; photosynthesis and \\ respiration; reciprocal transplantation; \\ vaccinium vitis-idaea.

\section{Correspondence} \\ Timo Saarinen, Department of Biosciences, \\ Fl-00014 University of Helsinki, PO Box 65, \\ Helsinki, Finland. E-mail: \\ timo.saarinen@helsinki.fi
}

doi:10.1111/j.1751-8369.2010.00152.x

\begin{abstract}
Northern plants have to cope with a wide range of overwintering conditions, as the depth and physical properties of snow show high spatial variation in the Arctic. The overwintering of lingonberry (Vaccinium vitis-idaea) was studied in a reciprocal transplantation experiment between two sub-Arctic microhabitats in northern Finland. The experiment was set up in the autumn, and physiological traits related to overwintering were measured at the time of snowmelt in the following spring. The origin of the plants was not a significant source of variation for most of the traits measured, whereas major differences were observed between the two sites. Plants that overwintered at an exposed site above the treeline showed high relative winter damage, assessed by the electrolyte leakage of the leaves. No severe winter damage was observed in the plants that overwintered under a moderate snowpack at a sheltered birch forest site. These plants were able to maintain their photosynthetic capacity through the winter. A low capacity of photosystem II and a very low capacity of $\mathrm{CO}_{2}$ uptake were characteristic of the exposed site, where low temperatures and high irradiation predominate during late winter. However, photosynthetic capacity was recovered within a few days when the plants were kept under favourable conditions after the field experiment. The content of nonstructural carbohydrates was low, probably because of high respiratory losses under the snow. This short-term study suggests that lingonberry, which occupies a wide range of microhabitats in the present climate, may thrive even if the overwintering conditions change as a result of climatic warming.
\end{abstract}

Arctic plants are adapted to a cold climate, but will have to cope with a warmer environment in the future (Crawford 2008a). Warming in the Arctic is expected to exceed the global mean warming by a factor of two (Christensen et al. 2007). The projected annual warming in the Arctic based on multi-model data sets is $5^{\circ} \mathrm{C}$ by the end of the 21 st century. Warming is expected to be largest in winter and smallest in summer. Along with increasing temperatures, snow conditions will also change markedly. The duration of the period with a permanent snow cover will decrease, the density of snow will increase and repeated freeze-thaw cycles will promote the formation of icy layers in the snowpack (Rasmus 2005). Depending on temperature conditions, both increases and decreases in the depth of snow are likely to occur. Higher precipitation may result in an increase in snow depth, provided that the temperature remains below zero. For example, a significant trend of increasing snow depth has been observed in northern Sweden (Kohler et al. 2006). Higher rainfall in winter together with above-zero temperatures may, however, reverse the trend.

The depth and duration of snow, and its physical properties, are fundamental factors affecting the overwintering of northern plants (Callaghan et al. 2004). Acting as an efficient insulator, a thick layer of porous snow protects the plants from frost damage (Havas 1966). Because of the high relative humidity of the air contained within the snow, plants covered by snow do not suffer from winter desiccation (Tahkokorpi et al. 2007). A thick layer of snow, however, substantially decreases the intensity of photosynthetically active radiation reaching the plants (Curl et al. 1972). Therefore, photosynthesis is thought to be strongly light-limited under the snow, even if the prevailing temperature is sufficient for metabolic processes.

A high spatial variation in snow depth is characteristic of Arctic ecosystems (McKay \& Gray 1981). Snow carried 
by wind from exposed habitats is deposited in sheltered snowbeds. Consequently, overwintering conditions may also show high spatial variability, even over short distances. During the growing season, sites close to snowbeds are cooler and moister than exposed ridges. The specialization of species to various microhabitats can be easily seen in the species composition of Arctic plant communities. Moreover, ecotypic or subspecies variation is a frequent character of many Arctic species (McGraw \& Antonovics 1983; Crawford 2008b). Some well-known examples of this phenomenon include Saxifraga oppositifolia (Teeri 1972) and Dryas octopetala (McGraw 1987). Both of these species show distinct morphological and physiological adaptations to the diverse climatic conditions of their microhabitats. It has been suggested that the high diversity of adaptations (both at the species and subspecies levels) to various microhabitats present in the current climate may facilitate the survival of Arctic plants in a warming climate (Crawford 2008a). The majority of studies on the adaptation of plants to various microhabitats have concentrated on the length of the snow-free period, and its effects on resource availability and the growth and reproductive success of plants during the growing season (Sonesson \& Callaghan 1991). Considering that winter is the longest season in the Arctic, surprisingly little is known about the overwintering of plants in different microhabitats.

The current study describes some short-term physiological responses of lingonberry (Vaccinium vitis-idaea) to changes in snow conditions. Lingonberry is a characteristic species of circumboreal coniferous forests, but it is also common in alpine and sub-Arctic sites, where it tolerates a range of snow conditions. We carried out a reciprocal transplantation experiment in two different microhabitats. One site was located in a sub-Arctic treeline forest characterized by a moderate layer of snow; the other site was located above the treeline on an exposed mound lacking snow during most of the winter. Physiological traits affecting the overwintering success of plants were studied. The following outcomes were hypothesized.

- Because of the lack of protecting snow cover, plants overwintering in the exposed habitat are prone to frost damage. Exposure to high irradiation in combination with freezing temperatures at the end of the winter causes additional stress, in the form of photoinhibition.

- A higher photosynthetic capacity is retained in the more sheltered forest habitat, even though the actual uptake of $\mathrm{CO}_{2}$ is probably strongly limited by the low light availability under the snow. However, high respiration rates in the warm environment under the snow gradually deplete the carbohydrate reserves during the winter.
- As a result of the diverse adaptive histories in different microhabitats, plants perform better in their original habitat than when transferred to new winter conditions characteristic of other habitats.

\section{Material and methods}

\section{Experimental set-up and weather conditions during the experiment}

A reciprocal transplant experiment was carried out in two microhabitats located in Kilpisjärvi, northern Finland, during the winter of 2005/06. One site was located in a sub-Arctic mountain birch (Betula pubescens ssp. czerepanovii) forest next to Kilpisjärvi Biological Station at $480 \mathrm{~m}$ a.s.l. $\left(69^{\circ} 03^{\prime} \mathrm{N}, 20^{\circ} 50^{\prime} \mathrm{E}\right)$. The ground layer is dominated by $V$. vitis-idaea and Empetrum nigrum, together with Deschampsia flexuosa. The site is characterized by a moderate snow cover during the winter: the average maximum snow depth is approximately $1 \mathrm{~m}$. The other site is an exposed mound located above the treeline on the southern slope of Jehkats Fjeld, at an altitude of $720 \mathrm{~m}$ a.s.l. The sparse ground layer vegetation is dominated by $V$. vitis-idaea and Empetrum nigrum, together with some individuals of Diapensia lapponica. There is usually very little, if any, snow at this site. The geographical distance between the two sites is about $3 \mathrm{~km}$. Hereafter, these two locations are referred to as the "sheltered" and the "exposed" habitat, respectively.

Twelve blocks of soil sized $10 \times 10 \mathrm{~cm}$ containing several shoots of lingonberry were dug up at both sites at the end of September 2005. The blocks were planted in plastic pots of corresponding size. Six of the pots were placed in topsoil at their original site; the other six were transferred to the other site. The plants were kept at the sites over the winter until April 2006, when snow started melting in the sheltered habitat.

A permanent snow cover was established in Kilpisjärvi in the beginning of November 2005 (data from the Finnish Meteorological Institute). A maximum snow depth of $59 \mathrm{~cm}$ was reached in early April, just before the start of melting. A minimum air temperature of $-38^{\circ} \mathrm{C}$ was recorded in the beginning of March 2006 (Finnish Meteorological Institute). Because of frequent temperature inversions, the minimum temperature recorded with a Hobo H8 outdoor/industrial temperature logger with TMCX-HA temperature sensors (Onset Computer Corporation, Bourne, MA, USA) in the exposed habitat was only $-22^{\circ} \mathrm{C}$ (Saarinen \& Lundell, unpubl. data). In spite of freezing air temperatures, temperatures measured close to the soil surface remained between $+1^{\circ} \mathrm{C}$ and $-2^{\circ} \mathrm{C}$ in the sheltered habitat through the whole winter (Saarinen \& Lundell, unpubl. data). 


\section{Measurements of photosynthetic capacity and chlorophyll fluorescence}

The ability of lingonberry to activate its photosynthesis was assessed at the end of the overwintering period. All the pots were collected on 16 April and allowed to recover under favourable conditions for 8 days. During the recovery, the plants were kept in a cold store $\left(+5^{\circ} \mathrm{C}\right)$ and illuminated with fluorescent tubes providing a photosynthetically active radiation (PAR) intensity of approximately $50 \mu \mathrm{mol}$ photons $\mathrm{m}^{-2} \mathrm{~s}^{-1}$. A natural photoperiod of 18-h day/6-h night was applied.

One-year-old leaves were collected from each pot on the first and eighth day of the recovery period. The light response of the photosynthesis of detached leaves was determined by measuring their photosynthesis at nine different light levels (0-1500 $\mu \mathrm{mol}$ photons $\left.\mathrm{m}^{-2} \mathrm{~s}^{-1}\right)$ using a portable photosynthesis system (LI-6400) with an added blue-red light source (LI-6400-02B Light Source; LI-COR Biosciences, Lincoln, NE, USA). The leaves were detached from the plants using a scalpel immediately prior to measuring.

The potential photochemical capacity of photosystem II was assessed by measuring the variable fluorescence $\left(F_{\mathrm{v}}\right)$ / maximum fluorescence $\left(F_{\mathrm{m}}\right)$ ratio of induced chlorophyll fluorescence in dark-adapted leaves. The leaves were dark-adapted in leaf clips for $30 \mathrm{~min}$ prior to the measurements. The leaves were illuminated with an actinic light $\left(400 \mu \mathrm{mol} \mathrm{m} \mathrm{m}^{-2} \mathrm{~s}^{-1}\right)$, and the subsequent induction of chlorophyll fluorescence was recorded with a PSM mark-II fluorometer (Biomonitor, Umeå, Sweden).

\section{Electrolyte leakage test}

Leaf damage induced during the wintering was assessed by measuring the relative electrolyte leakage from the leaves (Sutinen et al. 1992; Luoranen et al. 2004). Five randomly selected 1-year-old leaves from each pot were cut into six pieces each, rinsed briefly with deionized water, and then incubated in $10 \mathrm{ml}$ of deionized water in test tubes for $22 \mathrm{~h}$. After measuring the electric conductivity of the solute, the samples were killed by boiling them in a water bath for $60 \mathrm{~min}$. The samples were then allowed to cool, and the conductivity was measured again. Leaf damage was expressed as the ratio (in \%) of the conductivities measured before and after the boiling.

\section{Carbohydrate analyses}

For carbohydrate analyses, a bulk sample consisted of five l-year-old leaves collected from each pot. The leaves were immediately frozen and subsequently freeze-dried for later determination of soluble sugar and starch content. Soluble sugars were extracted with $80 \%(\mathrm{v} / \mathrm{v})$ ethanol, as described by Lundell et al. (2008). The total content of reducing sugars and sucrose was determined spectrophotometrically from the ethanol extract by means of the $p$-hydroxybenzoic acid hydrazide method described by Blakeney \& Mutton (1980). Storage carbohydrates were extracted with $30 \%(\mathrm{v} / \mathrm{v})$ perchloric acid from the residue pellets after extraction of soluble sugars (Lundell et al. 2008), and were then analysed using the anthrone method described by Quarmby \& Allen (1989).

\section{Statistical analyses}

The response of net photosynthesis to light was described by a nonrectangular hyperbolic function (Marshall $\delta$ Biscoe 1980). The function was fitted to each set of replicates of six measured light responses using the nonlinear regression procedure in the program SPSS 15.0 (SPSS Inc., Chicago, IL, USA). The horizontal asymptote parameter $\left(P_{\max }\right)$ of the curve, which indicates the theoretical maximum light-saturated rate of photosynthesis, was taken as a measure of the photosynthetic capacity.

The effects of the origin of the plants and the overwintering site on electrolyte leakage, chlorophyll fluorescence and carbohydrate reserves were analysed using a two-way ANOVA. The analyses were carried out using the univariate procedure of general linear models in sPSS 15.0.

\section{Results}

The relative electrolyte leakage, which is a measure of the permeability of the cell membranes, was higher in the exposed habitat (Fig. 1). The highest mean electrolyte leakage percentage, $29 \%$, was measured in the plants that originated from the exposed site and had overwintered at that same site. At the sheltered site the electrolyte leakages of plants of both origins were below 20\%. Both the origin of plants and the overwintering site were significant sources of variation in a two-way ANOvA, but the interaction of these factors was not significant (Table 1).

The content of nonstructural carbohydrates was highest in the plants that had overwintered at the exposed site (Fig. 2). Overwintering site was the only significant source of variation in a two-way ANOvA (Table 1). The lower content of nonstructural carbohydrates at the sheltered site resulted from a lower starch content. No significant differences were observed in the contents of reducing sugars (glucose + fructose) or sucrose between the two sites (Fig. 2).

There were marked differences in the potential capacity of photosystem II at the beginning of the recovery period. The mean $F_{\mathrm{v}} / F_{\mathrm{m}}$ ratio of chlorophyll fluorescence induc- 
tion ranged from 0.22 to 0.24 for the plants that had overwintered at the exposed habitat (Fig. 3a). Plants overwintering in the sheltered habitat showed higher values: the highest mean of 0.65 was measured in the leaves of plants originating from the exposed habitat. The origin of plants, the overwintering site and their interaction were all significant sources of variation (Table 1). However, site explained the major part of the variation observed. When the plants were transferred to favourable standard conditions after the field experiment, the low potential capacity of photosystem II of the plants that had overwintered at the exposed site partly recovered: after 8 days the $F_{\mathrm{v}} / F_{\mathrm{m}}$ ratios measured were increased two-fold compared with the values on the first day of the recovery period (Fig. 3b).

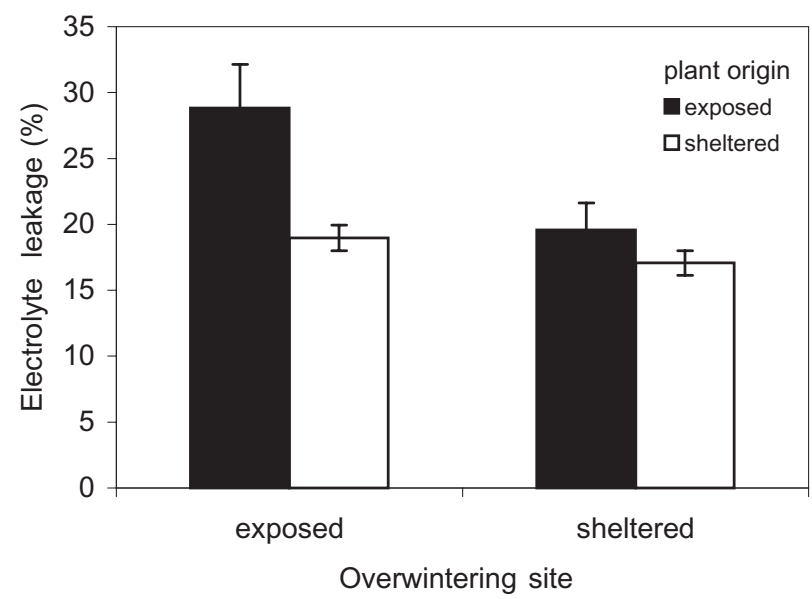

Fig. 1 Relative electrolyte leakage (\%) through cell membranes of the leaves of lingonberry (Vaccinium vitis-idaea) in a reciprocal transplant experiment in two sub-Arctic microhabitats. The measurements were carried out at the end of the field experiment in April 2006. Means \pm SE are shown.
Plants that had overwintered in the exposed habitat did not show any light response of $\mathrm{CO}_{2}$ uptake on the first day following the transfer to favourable recovery conditions (Fig. 4a). $\mathrm{CO}_{2}$ exchange was negative at all PAR intensities, indicating a steady loss of carbon. By contrast, a distinct light response was seen in the plants that had overwintered at the sheltered site. The maximum lightsaturated rate of photosynthesis, as indicated by the $P_{\max }$ parameter of the nonrectangular hyperbolic function, was slightly higher $\left(1.38 \mu \mathrm{mol} \mathrm{CO}_{2} \mathrm{~m}^{-2} \mathrm{~s}^{-1}\right)$ in the transplanted plants, compared with the plants in their original habitat $\left(0.82 \mu \mathrm{mol} \mathrm{CO} \mathrm{CO}^{-2} \mathrm{~s}^{-1}\right.$; Table 2$)$. The rates of dark respiration tended to be lower in the plants originating from the sheltered habitat. However, the 95\% confidence limits of all four groups overlapped.

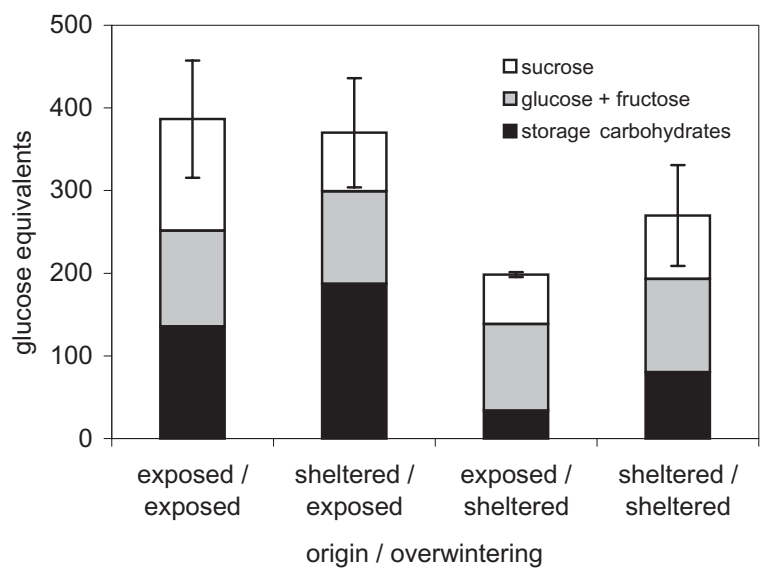

Fig. 2 Mean nonstructural carbohydrate contents ( $\mu$ g glucose equivalents $\mathrm{g}^{-1}$ dry weight) of the leaves of lingonberry (Vaccinium vitis-idaea) in a reciprocal transplant experiment in two sub-Arctic microhabitats. The measurements were carried out at the end of the field experiment in April 2006. The sum of storage carbohydrates, glucose + fructose and sucrose represents the total nonstructural carbohydrates, of which the standard error of the mean is shown.

Table 1 Results of a two-way analysis of variance on electrolyte leakage, contents of carbohydrates and chlorophyll fluorescence of the leaves of Vaccinium vitis-idaea in a reciprocal transplant experiment in two sub-Arctic habitats.

\begin{tabular}{|c|c|c|c|c|c|}
\hline Dependent variable & Source of variation & $d f$ & SS & $F$ & $P$ \\
\hline \multirow[t]{3}{*}{ Electrolyte leakage } & origin of plants & 1 & 292.12 & 7.80 & 0.012 \\
\hline & overwintering site & 1 & 271.26 & 7.24 & 0.015 \\
\hline & origin $\times$ site & 1 & 33.94 & 0.90 & 0.354 \\
\hline \multirow[t]{3}{*}{ Nonstructural carbohydrates } & origin of plants & 1 & 3852 & 0.22 & 0.643 \\
\hline & overwintering site & 1 & 113319 & 6.54 & 0.020 \\
\hline & origin $\times$ site & 1 & 10754 & 0.62 & 0.441 \\
\hline \multirow[t]{3}{*}{$F_{\mathrm{v}} / F_{\mathrm{m}}(1-$ day recovery) } & origin of plants & 1 & 0.0250 & 3.38 & 0.082 \\
\hline & overwintering site & 1 & 0.6382 & 86.13 & 0.000 \\
\hline & origin $\times$ site & 1 & 0.0516 & 6.96 & 0.016 \\
\hline \multirow[t]{3}{*}{$F_{\mathrm{v}} / F_{\mathrm{m}}$ (8-day recovery) } & origin of plants & 1 & 0.0410 & 4.90 & 0.040 \\
\hline & overwintering site & 1 & 0.1950 & 23.38 & 0.000 \\
\hline & origin $\times$ site & 1 & 0.0000 & 0.00 & 0.982 \\
\hline
\end{tabular}



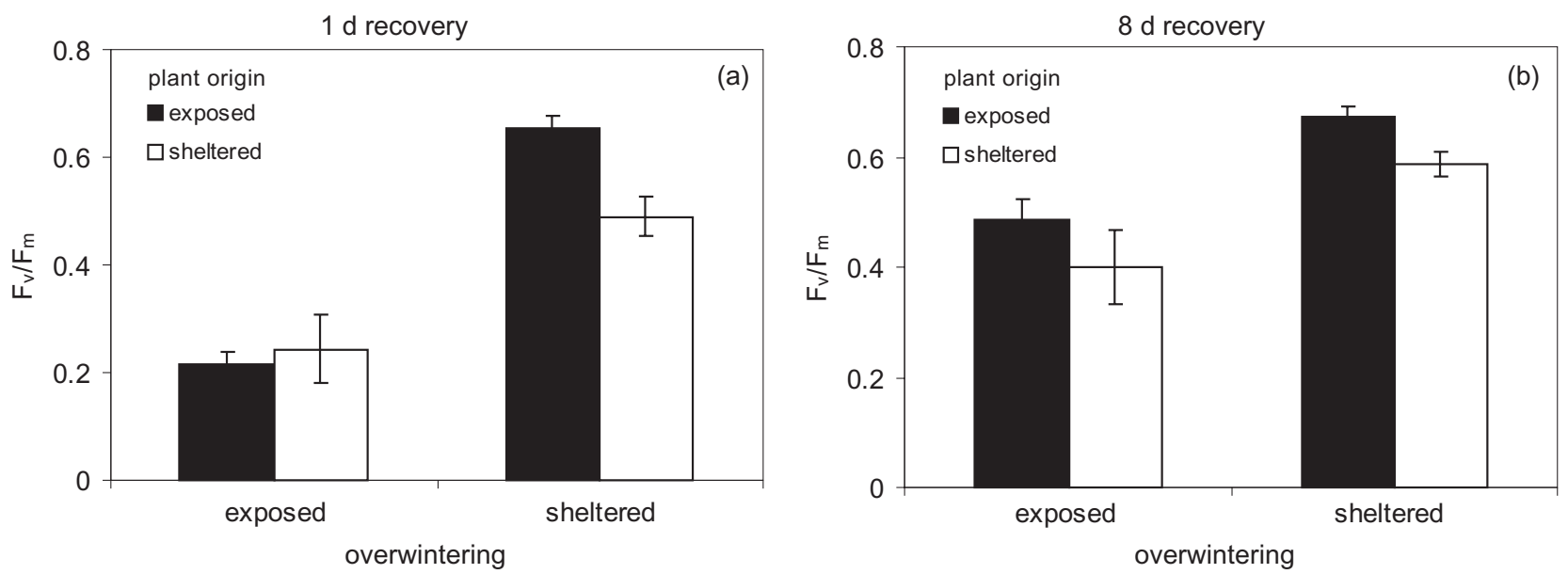

Fig. 3 Potential photochemical efficiency of photosystem II in the leaves of lingonberry (Vaccinium vitis-idaea) after (a) 1 and (b) 8 days of recovery following a reciprocal transplant experiment in two sub-Arctic microhabitats. The plants overwintered at the two study sites until April 2006, after which they were kept under standard conditions $\left(+5^{\circ} \mathrm{C}, 50 \mu \mathrm{mol}\right.$ photons $\mathrm{m}^{-2} \mathrm{~s}^{-1}, 16 \mathrm{~h}$ light $/ 8 \mathrm{~h}$ dark) for recovery. Means $\pm \mathrm{SE}$ are shown.
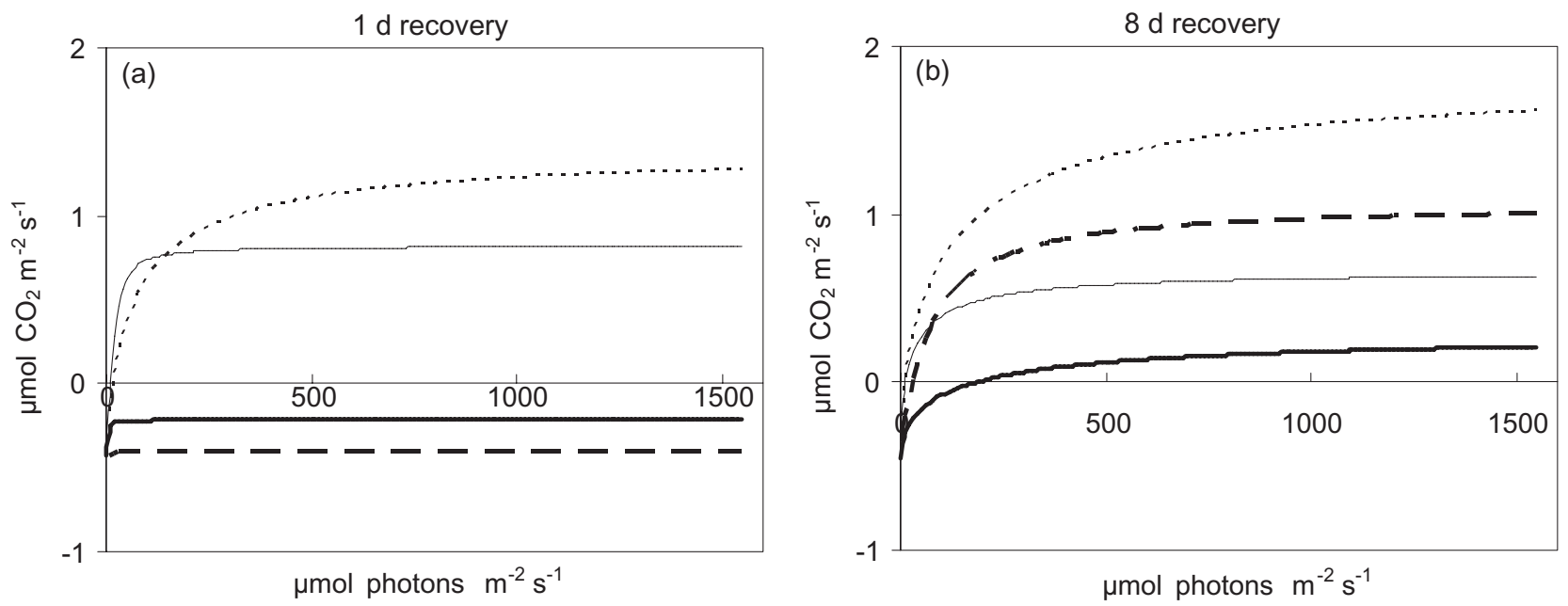

Fig. 4 Mean photosynthetic light responses of the leaves of lingonberry (Vaccinium vitis-idaea) after (a) 1 and (b) 8 days of recovery following a reciprocal transplant experiment in two sub-Arctic microhabitats. The plants overwintered at the two study sites until April 2006, after which they were kept under standard conditions $\left(+5^{\circ} \mathrm{C}, 50 \mu \mathrm{mol}\right.$ photons $\mathrm{m}^{-2} \mathrm{~s}^{-1}, 16 \mathrm{~h}$ light $/ 8 \mathrm{~h}$ dark) for recovery. Solid lines represent plants originating from a sheltered site; dashed lines represent plants originating from an exposed site. Thin lines represent plants that overwintered at the sheltered site; thick lines represent plants that overwintered at the exposed site.

After the 8-day recovery in standard conditions, a marked recovery of photosynthesis was observed in the plants that had overwintered at the exposed habitat (Fig. 4b). All the treatment groups showed a distinct light response of $\mathrm{CO}_{2}$ uptake, and the light-saturated rates were all positive (Table 2 ). The highest values of $P_{\max }$ were measured in plants originating from the exposed habitat. However, the $95 \%$ confidence limits of the parameter overlapped between the groups. No significant changes were observed in the rates of dark respiration.

\section{Discussion}

The physical environment of plants overwintering under snow is stable. The subnivean environment is characterized by slightly elevated $\mathrm{CO}_{2}$ concentrations, very low light intensities, and temperatures at and just above $0^{\circ} \mathrm{C}$ (Woolgrove \& Woodin 1996). Consequently, the risk of frost damage is low for most of the winter. The electrolyte leakage percentages of plants that had overwintered at the sheltered site in the current study were similar to 
Table 2 Light-saturated rate of net photosynthesis $\left(P_{\max }\right)$ and dark respiration $(R)$ of the leaves of Vaccinium vitis-idaea after 1 and 8 days of recovery following a reciprocal transplant experiment in two sub-Arctic microhabitats. The plants overwintered at the two study sites until April 2006 , after which they were kept under standard conditions $\left(+5^{\circ} \mathrm{C}, 50 \mu \mathrm{mol}\right.$ photons $\mathrm{m}^{-2} \mathrm{~s}^{-1}, 16 \mathrm{~h}$ light / $8 \mathrm{~h}$ dark) for recovery. The $95 \%$ confidence limits are given in parentheses; n.d., not detectable.

\begin{tabular}{|c|c|c|c|c|}
\hline & Origin & Overwintering & $\begin{array}{l}P_{\max } \\
\left(\mu \mathrm{mol} \mathrm{CO} \mathrm{CO}^{-2} \mathrm{~s}^{-1}\right)\end{array}$ & $\begin{array}{l}R \\
\left(\mu \mathrm{mol} \mathrm{CO}_{2} \mathrm{~m}^{-2} \mathrm{~s}^{-1}\right)\end{array}$ \\
\hline \multirow[t]{8}{*}{ Day 1} & sheltered & sheltered & 0.82 & 0.35 \\
\hline & & & $(0.72-0.92)$ & $(0.16-0.54)$ \\
\hline & sheltered & exposed & n.d. & 0.42 \\
\hline & & & & $(0.24-0.61)$ \\
\hline & exposed & sheltered & 1.38 & 0.81 \\
\hline & & & $(0.84-1.92)$ & $(0.65-0.96)$ \\
\hline & exposed & exposed & n.d. & 0.59 \\
\hline & & & & $(0.29-0.90)$ \\
\hline \multirow[t]{8}{*}{ Day 8} & sheltered & sheltered & 0.66 & 0.27 \\
\hline & & & (0.19-1.13) & $(0.05-0.58)$ \\
\hline & sheltered & exposed & 0.29 & 0.45 \\
\hline & & & $(-0.41-0.98)$ & $(0.19-0.71)$ \\
\hline & exposed & sheltered & 1.82 & 0.51 \\
\hline & & & $(0.93-2.71)$ & $(0.39-0.63)$ \\
\hline & exposed & exposed & 1.07 & 0.34 \\
\hline & & & $(0.74-1.39)$ & $(0.17-0.52)$ \\
\hline
\end{tabular}

what has been reported for lingonberry at a southern boreal site, where no winter damage was detected (Lundell et al. 2008). Higher leakage percentages at the exposed site, however, suggest damage to cell membranes. Contrary to our hypothesis, the plants originating from the exposed site showed the highest relative damage. The damage observed was not lethal: no visual damage was observed and the plants were able to recover their photosynthetic capacity rapidly. Because the minimum temperature of the whole winter was not very low $\left(-22^{\circ} \mathrm{C}\right)$, it is likely that stress factors other than freezing damage, such as winter desiccation, ice blast and exposure to high UV radiation, contributed to the damage observed (Sonesson \& Callaghan 1991; Taulavuori et al. 2005; Tahkokorpi et al. 2007). However, it is noteworthy that some early studies suggest that snow cover and exposure to frost damage may contribute to the upper distribution limit of $V$. vitis-idaea in the Scandinavian mountains (Ritchie 1955).

High concentrations of soluble sugars seem to promote the cold hardiness of plants; the causal mechanism, however, is not fully understood (Kalberer et al. 2006). In accordance with our hypothesis, the content of total nonstructural carbohydrates was low in the plants that had overwintered under a thick layer of snow in the current study. Because extreme sub-zero temperatures do not occur under a thick snowpack, sufficient frost hardiness may be acquired even with a lower concentration of carbohydrates. The lowest concentrations are equal to what was previously reported for Vaccinium growing in the southern boreal zone (Lundell et al. 2008). Therefore, the differences in carbohydrate contents between the two sites probably do not indicate an increased risk of frost damage.

Respiration at above-freezing temperatures is likely to have contributed to a loss of storage carbohydrates at the sheltered site during the winter. Plants that are able to adjust respiration to maintain a positive carbon balance may tolerate the predicted temperature increases in arctic regions (Cooper 2004). In our previous study in a boreal coniferous forest, where light is available even during winter, lingonberry maintained its photosynthetic capacity through the mild winter, and, consequently, no significant decrease in the content of carbohydrates was observed (Lundell et al. 2008). Because of the polar night characteristic of high-latitude regions, carbohydrate reserves cannot be replenished during the major part of the winter.

Down-regulation of photosynthesis is characteristic of sun-exposed evergreen sclerophytes (Adams et al. 2002; Adams et al. 2004; Zarter et al. 2006). This involves a decrease in several components of photosystem II and the employment of xanthophyll carotenoids in photoprotective processes where excessive energy is released as heat. In accordance with our hypotheses, the plants that overwintered in the exposed habitat showed a reduced efficiency of photosystem II and no ability for net $\mathrm{CO}_{2}$ gain. However, both the $F_{\mathrm{v}} / F_{\mathrm{m}}$ ratio and the lightsaturated rate of photosynthesis recovered substantially in a recovery period of 8 days. The recovery rate is of similar magnitude to those reported in other studies. According to Ensminger et al. (2008), the $F_{\mathrm{v}} / F_{\mathrm{m}}$ ratio of 
seedlings of Pinus sylvestris recovered rapidly after an exposure to freezing temperatures in the spring. Photosynthetic capacity recovered to pre-frost levels within a few days after the frost events. Likewise, the photosynthesis of severely frosted Hedera helix recovered in 10 days (Bauer \& Kofler 1987). In the aforementioned studies, as well as in the current study, plants were subject to favourable recovery conditions experimentally. In the field, however, less favourable conditions as a result of low temperatures and excessive irradiation may prevail for substantial periods of time after the snow has melted in the spring. Consequently, the recovery may also proceed more slowly under field conditions (e.g., Lundell et al. 2008).

A decrease in the photosynthetic capacity at exposed sites during winter, with a prolonged recovery period in the spring, may have significant implications for the annual photosynthetic production of evergreen plants. A main advantage of being evergreen is that evergreen plants are able to extend their photosynthetically active season. For example, Karlsson (1985) estimated that $V$. vitis-idaea growing at a sub-Arctic site may gain approximately $22 \%$ of its annual photosynthetic production in the early and late parts of the snowless season, when the congeneric deciduous species Vaccinium uliginosum does not possess any leaves. The lack of snow cover creates conditions that promote photoinhibition, and may thereby diminish the advantage of being evergreen. The ability of fast recovery of photosynthetic capacity under reasonably favourable conditions, which was observed in our study, is beneficial under such conditions. However, when snow melts later in sheltered habitats, the average air temperatures are already high, and, subsequently, the risk of photoinhibition is low.

Plants that had overwintered under snow at the sheltered site maintained their photosynthetic capacity. Several evergreen species, including $V$. vitis-idaea (Lundell et al. 2008), Pinus sylvestris (Sevanto et al. 2006) and several Arctic-alpine plants (Starr \& Oberbauer 2003; Larsen et al. 2007), have been observed to be able to photosynthesize during the winter. Under a thick snowpack, photosynthesis is strongly limited by light availability (Woolgrove \& Woodin 1996). Because the photosynthetic light compensation point of lingonberry is low (Karlsson 1985; Lundell et al. 2008), even low light intensities can be expected to enable significant rates of photosynthesis. Both a decreasing depth of snow and an increasing transmittance of light as a result of the increasing snow density of melting snow enhance light availability in the spring (Curl et al. 1972). When the conditions for photosynthesis improve, the carbohydrate reserves of plants have been observed to be replenished rapidly. For example, the carbohydrate concentration of the snowbed bryophyte Kiaeria starkei was shown to increase by $60 \%$ during a period of 2 weeks after the snowmelt (Woolgrove \& Woodin 1996).

High phenotypic plasticity is characteristic of lingonberry: shoot and leaf morphology may show substantial differences, even within a single clone, depending on the prevailing conditions (Ritchie 1955). The traits related to the overwintering of plants in exposed and sheltered microhabitats showed major differences between the two sites in the current study. High electrolyte leakage, a high content of nonstructural carbohydrates, low capacity of photosystem II and a loss of photosynthetic capacity during overwintering were characteristic of the snowless, exposed site. Our hypothesis that the plants overwintering at their site of origin would perform better compared with the transplanted ones was not supported by the results. The high plasticity of the overwintering traits of lingonberry may contribute to its wide distribution and ability to perform well in various habitats. The prospects of higher winter temperatures and changing snow conditions are considered to present a challenge for polar species. According to Crawford (2008a), heterogeneity in the Arctic and alpine habitats and ecotypic variation within species may facilitate the survival of cold-adapted plants as the climate warms. The same may also hold true for generalist species, such as lingonberry, occupying a wide range of microhabitats in the present climate.

\section{Acknowledgements}

Miguel Pinto kindly helped to set up the field experiment. Heikki Hänninen, Helena Åström and two anonymous reviewers made useful comments on the manuscript. This work has been supported by the Helsinki University Environmental Research Centre and the Academy of Finland, and by grants from the Maj and Tor Nessling Foundation to RL, and from the University of Helsinki to TS.

\section{References}

Adams W.W. III, Demmig-Adams B., Rosenstiel T.N., Brightwell A.K. \& Ebbert V. 2002. Photosynthesis and photoprotection in overwintering plants. Plant Biology 4 , 545-557.

Adams W.W. III, Zarter C.R., Ebert V. \& Demmig-Adams B. 2004. Photoprotective strategies of overwintering evergreens. Bioscience 54, 41-49.

Bauer H. \& Kofler R. 1987. Photosynthesis in frost-hardened and frost-stressed leaves of Hedera helix L. Plant, Cell and Environment 10, 339-346.

Blakeney A.B. \& Mutton L.L. 1980. A simple colorimetric method for the determination of sugars in fruit and vegetables. Journal of the Science of Food and Agriculture 31, 889-897. 
Callaghan T.V., Björn L.O., Chernov Y., Chapin T., Christensen T.R., Huntley B., Ims R.A., Johansson M., Jolly D., Jonasson S., Matveyeva N., Panikov N., Oechel W., Shaver G., Elster J., Henttonen J., Laine K., Taulavuori K., Taulavuori E. \& Zöckler C. 2004. Biodiversity, distribution and adaptations of Arctic species in the context of environmental Change. Ambio 33, 404-417.

Christensen J.H., Hewitson B., Busuioc A., Chen A., Gao X., Held I., Jones R., Kolli R.K., Kwon W.-T., Laprise R., Magaña Rueda V., Mearns L., Menéndez C.G., Räisänen J., Rinke A., Sarr A. \& Whetton P. 2007. Regional climate projections. In S. Solomon et al. (eds.): Climate change 2007. The physical science basis. Contribution of Working Group I to the fourth assessment report of the Intergovernmental Panel on Climate Change. Pp. 847-940. Cambridge: Cambridge University Press.

Cooper E.J. 2004. Out of sight, out of mind: thermal acclimation of root respiration in Arctic Ranunculus. Arctic, Antarctic, and Alpine Research 36, 308-313.

Crawford R.M.M. 2008a. Cold climate plants in a warmer world. Plant Ecology e Diversity 1, 285-297.

Crawford R.M.M. 2008b. Plants at the margin-ecological limits and climate change. Cambridge: Cambridge University Press.

Curl H., Hardy T. \& Ellermeier R. 1972. Spectral absorption of solar radiation in alpine snowfields. Ecology 53, 1189-1194.

Ensminger I., Schmidt L. \& Lloyd J. 2008. Soil temperature and intermittent frost modulate the rate of recovery of photosynthesis in Scots pine under simulated spring conditions. New Phytologist 177, 428-442.

Havas P. 1966. Pflanzenökologische Untersuchungen im Winter. I. Zur Bedeutung der Schneedecke für das Überwintern von Heidel- und Preisselbeere. (Plant ecological studies in winter. I. On the significance of snow cover for the overwintering of blueberry and lingonberry.) Aquilo Seria Botanica 4, 1-36.

Kalberer S.R., Wisniewski M. \& Arora R. 2006. Deacclimation and reacclimation of cold-hardy plants: current understanding and emerging concepts. Plant Science 171, 3-16.

Karlsson P.S. 1985. Photosynthetic characteristics and leaf carbon economy of a deciduous and an evergreen dwarf shrub: Vaccinium uliginosum L. and $V$. vitis-idaea L. Holarctic Ecology 8, 9-17.

Kohler J., Brandt O., Johansson M. \& Callaghan T. 2006. A long-term Arctic snow depth record from Abisko, northern Sweden, 1913-2004. Polar Research 25, 91-113.

Larsen K.S., Ibrom A., Jonasson S., Michelsen A. \& Beier C. 2007. Significance of cold-season respiration and photosynthesis in a subarctic heath ecosystem in northern Sweden. Global Change Biology 13, 1498-1508.

Lundell R., Saarinen T., Åström H. \& Hänninen H. 2008. The boreal dwarf shrub Vaccinium vitis-idaea retains its capacity for photosynthesis through the winter. Botany 86, 491-500.

Luoranen J., Repo T. \& Lappi J. 2004. Assessment of the frost hardiness of shoots of silver birch (Betula pendula) seedlings with and without controlled exposure to freezing. Canadian Journal of Forest Research 34, 11081118.

Marshall B. \& Biscoe P.V. 1980. A model for C3 leaves describing the dependence of net photosynthesis on irradiance. Journal of Experimental Botany 31, 29-39.

McGraw J.B. 1987. Experimental ecology of Dryas octopetala ecotypes. C. Field photosynthesis of reciprocal transplants. Holarctic Ecology 10, 303-311.

McGraw J.B. \& Antonovics J. 1983. Experimental ecology of Dryas octopetala ecotypes. I. Ecotypic differentiation and life cycle stages of selection. Journal of Ecology 71, 879-897.

McKay G.A. \& Gray D.M. 1981. The distribution of snow cover. In D.M. Gray \& D.H. Male (eds.): Handbook of snow. Principles, processes, management and use. Pp. 153-190. Elmsford: Pergamon Press.

Quarmby C. \& Allen S.E. 1989. Organic constituents. In S.E. Allen (ed.): Chemical analysis of ecological materials. Pp. 160-200. Oxford: Blackwell Scientific Publications.

Rasmus S. 2005. Snow pack structure characteristics in Finland-measurement and modelling. Report Series in Geophysics 48. Helsinki: Division of Geophysics, University of Helsinki.

Ritchie J.C. 1955. Biological flora of the British Isles. Vaccinium vitis-idaea L. Journal of Ecology 43, 701-708.

Sevanto S., Suni T., Pumpanen J., Grönholm T., Kolari P., Nikinmaa E., Hari P. \& Vesala T. 2006. Wintertime photosynthesis and water uptake in a boreal forest. Tree Physiology 26, 749-757.

Sonesson M. \& Callaghan T.V. 1991. Strategies of survival in plants of the Fennoscandian tundra. Arctic 44, 95-105.

Starr G. \& Oberbauer S.F. 2003. Photosynthesis of Arctic evergreens under snow: implications for tundra ecosystem carbon balance. Ecology 84, 1415-1420.

Sutinen M.-L., Palta J.P. \& Reich P.B. 1992. Seasonal differences in freezing stress resistance of needles of Pinus nigra and Pinus resinosa: evaluation of the electrolyte leakage method. Tree Physiology 11, 241-254.

Tahkokorpi M., Taulavuori K., Laine K. \& Taulavuori E. 2007. After-effects of drought-related winter stress in previous and current year stems of Vaccinium myrtillus L. Environmental and Experimental Botany 61, 85-93.

Taulavuori K., Taulavuori E. \& Laine K. 2005. Ultraviolet radiation and plant frost hardiness in the subarctic. Arctic, Antarctic and Alpine Research 37, 11-15.

Teeri J.A. 1972. Microenvironmental adaptations of local populations of Saxifraga oppositifolia in the High Arctic. PhD thesis, Duke University, Durham, NC, USA.

Woolgrove C.E. \& Woodin S.J. 1996. Ecophysiology of a snow-bed bryophyte Kiaeria starkei during snowmelt and uptake of nitrate from meltwater. Canadian Journal of Botany 74, 1095-1103.

Zarter C.R., Adams W.W. III, Ebbert V., Adamska I., Jansson S. \& Demmig-Adams B. 2006. Winter acclimation of PsbS and related proteins in the evergreen Arctostaphylos uva-ursi as influenced by altitude and light environment. Plant Cell and Environment 29, 869-878. 